\title{
The Relationship between the Number of Preserved Parathyroid Glands and Clinical Aspects after Total Thyroidectomy and Central Lymph Node Dissection in Papillary Thyroid Carcinoma
}

\author{
Chan-Eun Wie ${ }^{1}$, Soo-Geun Wang ${ }^{1}$, Byung-Joo Lee ${ }^{1}$, Yun-Sung Lim ${ }^{1}$, Yoon-Se Lee ${ }^{1}$, \\ In-Ju Kim ${ }^{2}$, Bo-Hyun Kim ${ }^{2}$, Sang-Soo Kim ${ }^{2}$, Yong-Il Cheon ${ }^{1}$ and Jin-Choon Lee ${ }^{1}$ \\ ${ }^{1}$ Departments of Otorhinolaryngology-Head and Neck Surgery, ${ }^{2}$ Internal Medicine and Division of Endocrinology \& Metabolism, \\ Pusan National University School of Medicine, Busan, Korea
}

\section{갑상선유두상암종에서 갑상선 전절제술 및 양측 중심 경부청소술 후 보존된 부갑상선의 개수와 임상적 양상과의 상관관계}

위찬은 ${ }^{1} \cdot$ 왕수건 $^{1} \cdot$ 이병주 $^{1} \cdot$ 임윤성 $^{1} \cdot$ 이윤세 $^{1} \cdot$ 김인주 $^{2} \cdot$ 김보현 $^{2} \cdot$ 김상수 $^{2} \cdot$ 천용일 $^{1} \cdot$ 이진춘 $^{1}$ 부산대학교 의학전문대학원 이비인후과학교실, ${ }^{1}$ 내분비내과학교실 ${ }^{2}$

Received March 27, 2013 Revised May 17, 2013 Accepted June 8, 2013 Address for correspondence Jin-Choon Lee, MD, PhD Department of OtorhinolaryngologyHead and Neck Surgery, Pusan National University School of Medicine, 179 Gudeok-ro, Seo-gu, Busan 602-739, Korea Tel $+82-51-240-7335$ Fax $+82-51-246-8668$ E-mail1jc0209@hanmail.net
Background and Objectives To identify the relation between the preservation status of the parathyroid glands and the risk of hypoparathyroidism after total thyroidectomy and central lymph node dissection in papillary thyroid carcinoma.

Subjects and Method A retrospective review was carried out for the medical records of 63 patients with papillary thyroid carcinoma (PTC), who satisfied our inclusion criteria and received treatment at the Department of Otolaryngology-Head and Neck Surgery, Hospital from May 2010 to December 2011. Patients with PTC who underwent total thyroidectomy with central lymph node dissection (CLND) were included and grouped according to the number of preserved parathyroid glands as follows: Group 1 (with four intact glands), Group 2 (three intact glands), Group 3 (less than two intact glands). The total and ionized serum calcium and intact parathyroid hormone levels of each group were monitored after the surgery. Patients with postoperative symptomatic hypocalcemia were considered to have postoperative hypoparathyroidism and received calcium/vitamin D therapy. The hypoparathyroidism was considered to be permanent when calcium/vitamin D therapy was still required six months after surgery.

Results Out of 63 cases of total thyroidectomy with CLND, 31 (49.2\%) showed postoperative hypoparathyroidism as demonstrated by laboratory findings. Permanent hypoparathyroidism, however, was not observed in these cases. The development of hypoparathyroidism was not significantly related with the number of preserved parathyroid glands.

Conclusion To prevent postoperative hypoparathyroidism following total thyroidectomy and CLND, at least two parathyroid glands should be preserved in situ with an intact blood supply in order to prevent permanent hypoparathyroidism after the surgery.

Korean J Otorhinolaryngol-Head Neck Surg 2013;56:431-5

Key Words Hypocalcemia · Parathyroid · Total thyroidectomy.

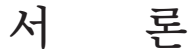

갑상선 절제시 영구적 부갑상선 기능저하는 물론이고 일과
성 부갑상선 기능저하의 빈도를 최소화하기 위해서는 가능한 한 모든 부갑상선을 혈관과 같이 원상태로 보존하도록 노력 하는 것이 원칙이다.1) 그러나 실제 수술시 모든 부갑상선을 확 
인 보존하는 것이 항상 가능하지는 않다. 수술 후 부갑상선 기 능저하증은 갑상선 전절제술 후 가장 많이 발생하며 때로는 가장 심각한 합병증이 되기도 한다.') 수술 후 부갑상선 기능저 하증은 갑상선 피막에 근접한 수술시 혈행차단으로 인한 부갑 상선 기능의 저하, 우연히 1 개 이상의 부갑상선의 제거, 반회후 두신경을 따라서 림프절 청소술시 부갑상선의 손상, 혈종 생성 으로 인해 야기될 수 있다.3) 임상적으로 부갑상선 기능저하증 은 저칼슘혈증의 증상으로 입 주위 감각이상, 손발의 감각이 상, 근육경련, 강직, 발작, 흥통, 후두경련 및 천명, 전신쇠약, 불안 등의 증상과 Chvostek sign, Trousseau sign 등이 나타 날 수 있으며 이는 환자들에게 부담이 되어 삶의 질을 저해하 는 결과를 줄 수 있다. ${ }^{3)}$ 따라서 부갑상선 기능저하증은 임상의 에게 갑상선 수술 범위에 대한 제한을 가져올 수 있다.

저자는 갑상선 전절제술 및 양측 중심 경부청소술 후 보존 된 부갑상선 개수와 부갑상선 기능저하증과의 상관관계를 알 아보고 또한 부갑상선 보존에 영향을 주는 인자들을 확인해 보고자 본 연구를 시행하였다.

\section{대상 및 방법}

\section{대 상}

2010년 5월부터 2011년 12월까지 부산대학교병원 이비인후두경부외과에서 갑상선 전절제술 및 양측 중심 경부청소술을 시행 받은 63명을 대상으로 후향적으로 의무기록을 분석하 였다. 모든 환자들은 수술 전 초음파와 초음파 유도하 세침흡 인검사를 시행하여 갑상선유두상암으로 진단받아 갑상선 전 절제술 및 양측 중심 경부청소술을 시행한 예를 대상으로 하 였다. 갑상선 기능항진증, 갑상선종, 갑상선 여포암, 갑상선 수 질암, 갑상선 전절제술 및 편측 중심 경부청소술, 갑상선 수술 시 제거된 부갑상선을 자가이식한 경우는 제외하였다. 63 예는 수술 후 갑상선유두상암으로 최종 진단받았다.

\section{방 법}

갑상선 전절제술 및 양측 중심 경부청소술은 숙달된 두경 부 외과의사 1 명에 의해 이뤄졌으며 중심 경부구획의 경계는 위로는 설골(hyoid bone), 양측은 경동맥(carotid a.) 앞쪽은 심부 근막의 천층(superficial layer of deep cervical fascia), 뒤쪽은 심부 근막의 심층(deep layer of deep cervical fascia), 아래쪽은 흥골 절흔(sternal notch)으로 정의하였다. ${ }^{4)}$ 종양의 크기 $1 \mathrm{~cm}$ 이상, 육안적으로 피막 침범이 있을 때, 림프절 전 이가 수술 중 의심되었을 때, 동결조직검사상 동측 림프절 전 이가 확인되었을 경우에 양측 중심 경부청소술이 시행되었다.

부갑상선은 육안으로 확인하였으며 갑상선으로부터 주의 깊
게 박리하여 모든 부갑상선을 확인하고 보존하기 위해 노력 하였다. 혈중 총 칼슘(total calcium)과 이온화 칼슘(ionized calcium)을 수술 전, 수술 후 3일까지 매일 측정하였고 수술 후 3일째 intact parathyroid hormone(iPTH)을 측정하였다. 부 갑상선 기능저하증의 정의는 혈중 총 칼슘치가 $8.0 \mathrm{mg} / \mathrm{dL}$ 이하(참고치, $8.5 \sim 10.3 \mathrm{mg} / \mathrm{dL}$ ), 이온화 칼슘치가 $0.9 \mathrm{mmol} / \mathrm{L}$ 이하(참고치, $1.0 \sim 1.2 \mathrm{mg} / \mathrm{dL}$ )이거나 $\mathrm{iPTH}$ 가 $10 \mathrm{pg} / \mathrm{mL}$ 미만 (참고치, 10 65 pg/mL)인 경우로 하였다. 영구적인 부갑상 선 기능저하증은 혈중 총 칼슘, 이온화 칼슘과 $\mathrm{iPTH}$ 를 갑상 선 전절제술 후 6 개월째 마지막으로 측정하여 평가하였다. 만 약 혈중 칼슘과 $\mathrm{iPTH}$ 가 6 개월 이내 정상 수치로 돌아왔으면 일시적 부갑상선 기능저하증으로 정의하였고, 정상수치로 돌 아오지 않았을 경우 영구적 부갑상선 기능저하증으로 분류하 였다.

수술 후 보존된 부갑상선의 개수와 수술 후 혈중 총 칼슘, 이온화칼슘 그리고 $\mathrm{iPTH}$ 와의 상관관계를 조사하였고, 종양 의 크기, 중심 경부림프절 침범 유무, 피막 침범여부, 절제 변연 양성 유무, 하시모토씨 갑상선염 동반 여부와 보존된 부갑상 선의 개수와의 상관관계도 조사하여 부갑상선 보존에 영향 을 주는 인자들도 확인하고자 하였다.

통계처리는 SPSS 12.0 프로그램(SPSS Inc., Chicago, IL, USA)을 이용하여 chi square test, Fisher's exact test와 oneway ANOVA를 시행하였고, 유의 수준은 $p<0.05$ 로 하였다.

\section{결 과}

\section{연령 및 성별 분포}

전제 63예의 연령은 22세부터 68세로 평균 나이는 51.1세였 고, 모두 여성이었다.

\section{병리 조직학적 소견}

조사한 전체 63예 환자의 갑상선 수술 후 최종 확인된 병리 검사 결과는 모두 유두상암이었고 하시모토씨 갑상선염이 유 두상암과 동반된 경우가 3예 있었다. 중심 경부청소술이 시행 된 63명에서 림프절 전이가 발견된 경우는 45예(71.4\%)였고, 피막 침범은 45예(71.4\%)에서 확인되었다. 제거된 림프절의 개 수는 평균 $7.7 \pm 3.6$ 개, 종양크기는 평균 $1.2 \pm 0.6 \mathrm{~cm}$ 였다.

\section{갑상선 전절제술 중 부갑상선 확인 개수}

수술 중 부갑상선은 3개가 확인된 경우가 38예(60.3\%)로 가 장 많았으며, 4 개 모두 확인된 경우가 9예(14.3\%), 2개가 확인 된 경우가 16예(25.4\%)였고, 1개 이하로 확인된 경우는 없었다. 

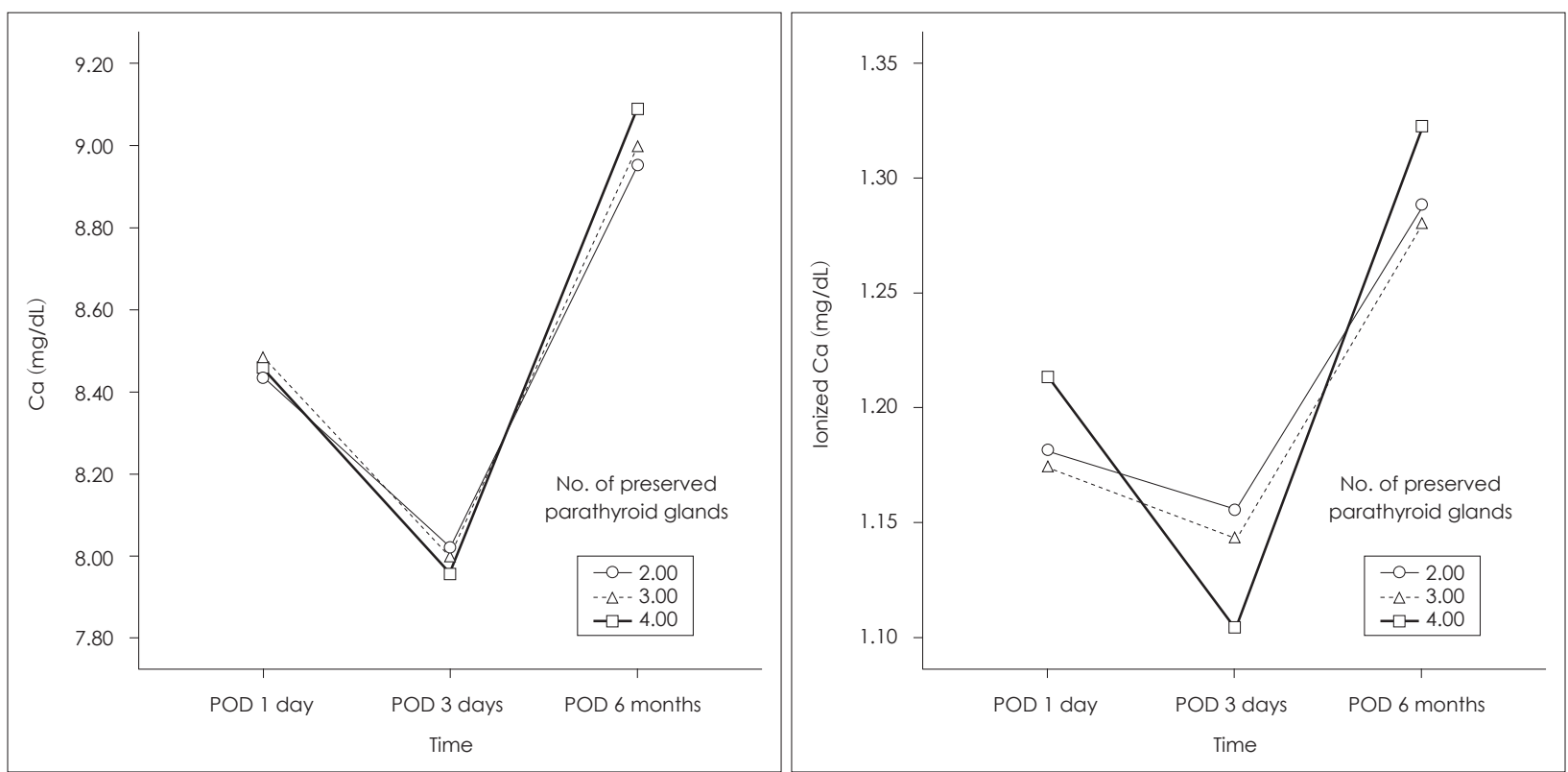

Fig. 1. Correlation between the number of preserved parathyroid glands and postoperative change of total calcium and ionized serum calcium level. POD: postoperative day.

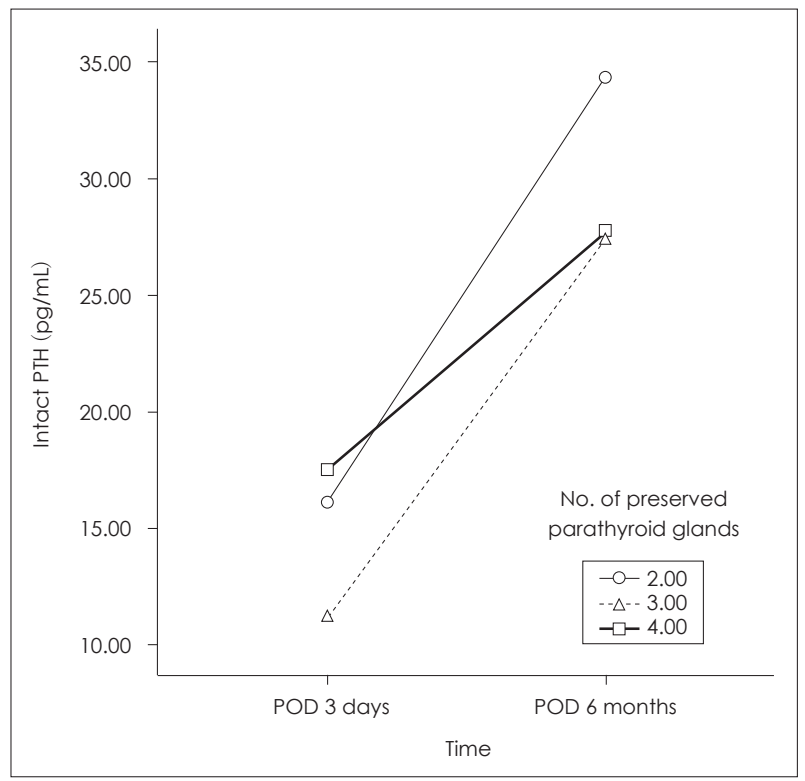

Fig. 2. Correlation between the number of preserved parathyroid glands and postoperative change of intact PTH level. PTH: parathyroid hormone, POD: postoperative day.

\section{갑상선 전절제술 중 정상 보존된 부갑상선의 수와 술 후 혈중 총 칼슘, 이온화칼슘, iPTH의 변화}

수술 중 4개의 부갑상선이 전부 확인된 예는 9예였고, 이 중 일시적 부갑상선 기능저하는 3 예(33.3\%)에서 발생하였다. 3 개 의 부갑상선이 확인된 경우가 38예로 가장 많았고 이 중 부갑 상선 기능저하증은 21 예(55.2\%)에서 발생하였다. 부갑상선이 2개 확인된 16예 중에서는 7예(43.7\%)에서 발생하였다. 수술 후 시간경과에 따른 혈중 총 칼슘, 이온화칼슘, $\mathrm{iPTH}$ 의 수치
가 정상화되는 경향(Figs. 1 and 2)은 있었으나 보존된 부갑상 선의 개수가 많은 것과 혈중 총 칼슘, 이온화칼슘, $\mathrm{iPTH}$ 의 수 치가 높아지는 것과는 통계적인 의의는 없었다(Table 1 and 2).

\section{수술 중 부갑상선 수 보존에 영향을 미치는 인자들}

\section{종양크기와 보존된 부갑상선 개수와의 관계}

종양크기는 평균 $1.2 \pm 0.6 \mathrm{~cm}$ 였으며, 종양 크기가 작을수 록 수술 후 보존된 부갑상선의 개수가 많았으며 통계학적으 로 유의한 연관성을 보였다 $(p=0.026)$ (Table 3).

\section{중심 경부림프절 전이와 보존된 부갑상선 개수와의 관계}

중심 경부림프절 전이가 없는 군, 전이가 있는 군으로 나누 어 수술 후 보존된 부갑상선 개수와의 관계를 보았지만 통계 학적 의의는 없었다 $(p=0.074)$ (Table 3$)$.

\section{피막 침범여부에 따른 보존된 부갑상선 개수와의 관계}

전체 환자 63예 중 45예(71.4\%)에서 피막 침범이 있었으며 피막 침범 유무와 수술 후 보존된 부갑상선 개수와의 관계 는 통계학적 의의는 없었다( $p=0.393)$ (Table 3).

\section{절제연 양성 여부와 보존된 부갑상선 개수와의 관계}

전체 환자 63예 중 4예(6.3\%)에서 절제연이 양성이었으며, 절 제연 양성 유무와 보존된 부갑상선 개수와의 관계는 통계학 적 의의는 없었다 $(p=1.000)$ (Table 3). 
Table 1. Postoperative total calcium and ionized serum calcium levels obtained after thyroid surgery

\begin{tabular}{|c|c|c|c|c|c|c|}
\hline \multirow{2}{*}{$\begin{array}{l}\text { No. of preserved } \\
\text { parathyroid glands }\end{array}$} & \multicolumn{3}{|c|}{ Postoperative Ca level } & \multicolumn{3}{|c|}{ Postoperative lonized Ca level } \\
\hline & 1 day & 3 days & 6 months & 1 day & 3 days & 6 months \\
\hline 2 & $8.4 \pm 0.5$ & $8.0 \pm 0.5$ & $9.0 \pm 0.5$ & $1.1 \pm 0.1$ & $1.2 \pm 0.1$ & $1.2 \pm 0.1$ \\
\hline 3 & $8.5 \pm 0.5$ & $8.0 \pm 0.7$ & $9.0 \pm 0.5$ & $1.1 \pm 0.1$ & $1.1 \pm 0.1$ & $1.2 \pm 0.1$ \\
\hline 4 & $8.5 \pm 0.4$ & $8.0 \pm 0.9$ & $9.1 \pm 0.4$ & $1.2 \pm 0.1$ & $1.1 \pm 0.1$ & $1.3 \pm 0.1$ \\
\hline
\end{tabular}

Table 2. Postoperative intact parathyroid hormone (iPTH) levels and patient with hypoparathyroidism obtained after thyroid surgery

\begin{tabular}{cccccc}
\hline \multirow{2}{*}{$\begin{array}{c}\text { No. of preserved } \\
\text { parathyroid glands }\end{array}$} & \multicolumn{2}{c}{ Postoperative iPTH level } & & \multicolumn{2}{c}{ Patient with hypoparathyroidism } \\
\cline { 2 - 3 } \cline { 5 - 6 } & 3 days & 6 months & & Temporary cases $(\%)$ & Permanent cases (\%) \\
\hline 2 & $16.1 \pm 10.7$ & $34.3 \pm 45.7$ & & $7 / 16(43.7)$ & $0.0)$ \\
4 & $11.2 \pm 10.3$ & $27.3 \pm 16.8$ & & $21 / 38(55.2)$ & $0(0.0)$ \\
& $17.5 \pm 13.3$ & $27.7 \pm 8.6$ & & $3 / 9(33.3)$ & $0(0.0)$ \\
\hline
\end{tabular}

Table 3. Correlation between the number of preserved parathyroid glands and mass size, central lymph node metastasis, extrathyroid extension, positive resection margin, hashimoto's thyroiditis

\begin{tabular}{|c|c|c|c|c|c|}
\hline \multirow{2}{*}{ Variables } & \multirow{2}{*}{ Group } & \multicolumn{3}{|c|}{ No. of preserved parathyroid glands } & \multirow{2}{*}{$p$} \\
\hline & & $2(n=16)$ & $3(n=38)$ & $4(n=9)$ & \\
\hline \multirow[t]{3}{*}{ Mass size } & $\leq 1 \mathrm{~cm}$ & 10 & 20 & 5 & \multirow{3}{*}{0.026} \\
\hline & $1<\leq 2 \mathrm{~cm}$ & 1 & 15 & 4 & \\
\hline & $2<\leq 4 \mathrm{~cm}$ & 5 & 3 & 0 & \\
\hline \multirow[t]{2}{*}{ Central lymph node metastasis } & No & 2 & 11 & 5 & \multirow{2}{*}{0.074} \\
\hline & Yes & 14 & 27 & 4 & \\
\hline \multirow[t]{2}{*}{ Extrathyroid extension } & No & 3 & 11 & 4 & \multirow{2}{*}{0.393} \\
\hline & Yes & 13 & 27 & 5 & \\
\hline \multirow[t]{2}{*}{ Positive resection margin } & No & 15 & 35 & 9 & \multirow{2}{*}{1.000} \\
\hline & Yes & 1 & 3 & 0 & \\
\hline \multirow[t]{2}{*}{ Hashimoto's thyroiditis } & No & 16 & 35 & 9 & \multirow{2}{*}{0.715} \\
\hline & Yes & 0 & 3 & 0 & \\
\hline
\end{tabular}

\section{하시모토씨 갑상선염 동반여부와 보존된 부갑상선 개수와의 관계}

전체 환자 63예 중 3예(4.7\%)에서 하시모토씨 갑상선염이 동 반되어 있었으며 수술 후 보존된 부갑상선 개수와의 관계는 통계학적 의의는 없었다 $(p=0.715)$ (Table 3).

\section{고 찰}

갑상선 전절제술 후 발생하는 부갑상선 기능저하증은 반회 후두신경마비와 함께 임상적으로 중요하며 때로는 심각한 합 병증을 유발시키기도 한다. 하지만 이러한 수술 후 일시적 혹 은 영구적인 부갑상선 기능저하증을 유발시키는 인자에 대 해서는 논란이 있다. 수술시 영구적인 반회후두신경손상을 피 하기 위해 반회후두신경 주위로 세심하게 박리할 경우 부갑 상선으로 가는 혈류에 부분적으로 영향을 줄 수 있으며 이것 은 일시적인 저칼슘혈증을 유발할 수 있다. 또한 갑상선 수술 시 동측과 반대측 중심 경부청소술을 동시에 시행할 경우 반 회후두신경의 손상 및 부갑상선의 손상과 기능저하로 인한
부갑상선 기능저하증의 발생빈도가 높아진다. ${ }^{5)}$

수술 후 부갑상선 기능저하증의 정의는 혈청 칼슘 수치에 기준을 두고 있는데 최근 $\mathrm{iPTH}$ 를 수술 중, 수술 전, 후 혹은 수술 직후 측정하여 수술 후 부갑상선 기능저하를 보다 분명 히 예측할 수 있다고 보고되고 있다. ${ }^{4)}$ 이번 연구에서 수술 후 부갑상선 기능저하증은 혈중 총 칼슘치가 $8.0 \mathrm{mg} / \mathrm{dL}$ 이하 (참고치, $8.5 \sim 10.3 \mathrm{mg} / \mathrm{dL}$ ), 이온화 칼슘치가 $0.9 \mathrm{mmol} / \mathrm{L}$ 이 하(참고치, $1.0 \sim 1.2 \mathrm{mg} / \mathrm{dL}$ )이거나 $\mathrm{iPTH}$ 가 $10 \mathrm{pg} / \mathrm{mL}$ 미만(참 고치, 10 65 pg/mL)인 경우로 하였다. 수술 후 언제 검사를 하는 것이 부갑상선 기능저하증을 예측하는 데 도움이 되는지 는 논란이 있으나 몇몇 문헌에서는 수술 후 48시간 이내 혈청 칼슘치의 감소가 부갑상선 기능저하증을 예측하는 데 안전한 예측인자라 하였다. ${ }^{6}$

부갑상선의 수는 좌우에 각각 상, 하 부갑상선이 있어 4 개인 경우가 $84 \%$ 이며, 3 개인 경우가 $3 \%, 5$ 개 이상인 경우가 $13 \%$ 이 다. 주로 하갑상선동맥이 부갑상선에 혈액을 공급하며, 때로 는 상갑상선동맥 또는 상갑상선동맥과 하갑상선동맥의 연결 혈관이 혈액을 공급하기도 한다. 상부갑상선의 위치는 비교적 
일정하여 약 $80 \%$ 가 반회후두신경과 하갑상선동맥이 교차하 는 부위에서 $1 \mathrm{~cm}$ 상부의 윤상갑상접합부(cricothyroid junction)에 존재하며, 그 다음으로 상극갑상선 후면, 후인두 부위 순이다. ${ }^{8)}$ 하부갑상선은 흥선의 발생과 밀접한 관계를 가지고 있으므로 위치의 변이가 많다. $50 \%$ 이상이 갑상선의 하극에 존재하며, $28 \%$ 는 갑상흥선인대(thyrothymic ligament) 주 위 또는 상부종격동의 흥선 내에 존재한다. ${ }^{9)}$ 이러한 이유로 부갑상선은 중심 경부청소술을 적극적으로 시행하는 경우에 손상을 받을 가능성이 높아질 수 있다. Wong과 Lang ${ }^{10)}$ 에 따 르면 일시적 부갑상선 기능저하증의 발생률은 편측 중심 경부 청소술(20.5\%), 양측 중심 경부청소술(48\%)로 양측 중심 경부 청소술시 일시적인 부갑상선 기능저하증이 더 높았다고 하였 다. 이 때문에 대부분 술자는 양측 중심 경부림프절의 제거보 다는 편측 중심 경부림프절의 제거 혹은 촉지되는 비대한 림 프절만을 선별하여 제거하려는 경향이 있다. 본 연구에서는 양측 중심 경부청소술을 시행한 63예 중 31예(49.2\%)에서 일 시적 부갑상선 기능저하가 발생하였으나 영구적 부갑상선 기 능저하를 보인 예는 없었다. 그리고 일시적 부갑상선 기능저 하증은 정주용 또는 경구 칼슘제재의 투여로서 수일 또는 수주 내에 호전되었다. 수술 후 보존된 부갑상선의 개수가 많 을수록 부갑상선 기능저하증이 적게 발생하는 것과 통계적 유 의성은 없었다. 본 연구에서 부갑상선을 적어도 2 개 이상 보존 한다면 영구적 부갑상선 기능저하는 보이지 않을 것이라는 결 과를 알 수 있었다. 편측 중심 경부청소술에 비해 양측 중심 경부청소술시에 부갑상선의 손상 위험은 높지만 조심스러운 박리를 통하여 부갑상선을 최대한 보존하려고 노력하여 적
어도 2개 이상의 부갑상선을 보존할 수 있다면 영구적인 부갑 상선 기능저하증은 예방할 수 있을 것이라고 사료된다.

\section{REFERENCES}

1) Wijnbladh H. Postoperative tetany; a study based upon 40 treated cases. Acta Endocrinol (Copenh) 1952;10(1):1-16.

2) Asari R, Passler C, Kaczirek K, Scheuba C, Niederle B. Hypoparathyroidism after total thyroidectomy: a prospective study. Arch Surg 2008;143(2):132-7; discussion 138.

3) Pattou F, Combemale F, Fabre S, Carnaille B, Decoulx M, Wemeau $\mathrm{JL}$, et al. Hypocalcemia following thyroid surgery: incidence and prediction of outcome. World J Surg 1998;22(7):718-24.

4) Robbins KT, Shaha AR, Medina JE, Califano JA, Wolf GT, Ferlito A, et al. Consensus statement on the classification and terminology of neck dissection. Arch Otolaryngol Head Neck Surg 2008;134(5): 536-8.

5) Cheah WK, Arici C, Ituarte PH, Siperstein AE, Duh QY, Clark OH. Complications of neck dissection for thyroid cancer. World J Surg 2002;26(8):1013-6.

6) Bentrem DJ, Rademaker A, Angelos P. Evaluation of serum calcium levels in predicting hypoparathyroidism after total/near-total thyroidectomy or parathyroidectomy. Am Surg 2001;67(3):249-51; discussion 251-2.

7) Akerström G, Malmaeus J, Bergström R. Surgical anatomy of human parathyroid glands. Surgery 1984;95(1):14-21.

8) Page C, Foulon P, Strunski V. The inferior laryngeal nerve: surgical and anatomic considerations. Report of 251 thyroidectomies. Surg Radiol Anat 2003;25(3-4):188-91.

9) Pellitteri PK, Sofferman RA, Randolph GW. Surgical management of parathyroid disorders. In: Cummings CW, Flint PW, Harker LA, et al., editors. Cumming's Otolaryngoloty: Head and Neck Surgery. 4th ed. Philadelphia: Mosby;2004. p.2724-78.

10) Wong KP, Lang BH. The role of prophylactic central neck dissection in differentiated thyroid carcinoma: issues and controversies. $\mathrm{J}$ Oncol 2011;2011:127929. 